\title{
Investigations on DNA binding in rat liver and in Salmonella and on mutagenicity in the Ames test by emodin, a natural anthraquinone
}

\author{
R. Bösch, U. Friederich, W.K. Lutz, E. Brocker, M. Bachmann and Ch. Schlatter \\ Institute of Toxicology, ETH and University of Zurich, $\mathrm{CH}-8603$ Schwerzenbach (Switzerland)
}

(Received 6 November 1986)

(Accepted 19 January 1987)

Keywords: DNA binding; (Rat liver); (Salmonella); Ames test; Emodin; Anthraquinone glycosides, natural.

\section{Summary}

Emodin (1,6,8-trihydroxy-3-methylanthraquinone), an important aglycone found in natural anthraquinone glycosides frequently used in laxative drugs, was mutagenic in the Salmonella/mammalian microsome assay (Ames test) with a specificity for strain TA1537. The mutagenic activity was activationdependent with an optimal amount of S9 from Aroclor 1254-treated male Sprague-Dawley rats of 20\% in the $\mathrm{S} 9 \mathrm{mix}(\mathrm{v} / \mathrm{v})$ for $10 \mu \mathrm{g}$ emodin per plate. Heat inactivation of the $\mathrm{S} 9$ for $30 \mathrm{~min}$ at $60^{\circ} \mathrm{C}$ prevented mutagenicity. The addition of the cytochrome P-448 inhibitor 7,8-benzoflavone ( 18.5 nmoles per plate) reduced the mutagenic activity of $5.0 \mu \mathrm{g}$ emodin per plate to about one third, whereas the P-450 inhibitor metyrapone (up to 1850 nmoles per plate) was without effect. To test whether a metabolite binds covalently to Salmonella DNA, $\left[10-{ }^{14} \mathrm{C}\right]$ emodin was radiosynthesized, large batches of bacteria were incubated with $\left[10-{ }^{14} \mathrm{C}\right]$ emodin and DNA was isolated. [G- $\left.{ }^{3} \mathrm{H}\right] \mathrm{Aflatoxin} \mathrm{B}_{1}\left(\mathrm{AFB}_{1}\right)$ was used as a positive control mutagen known to act via DNA binding. DNA obtained after aflatoxin treatment could be purified to constant specific activity. With emodin, the specific activity of DNA did not remain constant after repeated precipitations so that it is unlikely that the mutagenicity of emodin is due to covalent interaction of a metabolite with DNA. The antioxidants vitamin $\mathrm{C}$ and $\mathrm{E}$ or glutathione did not reduce the mutagenicity. Emodin was also negative with strain TA102. Thus, oxygen radicals are probably not involved. When emodin was incubated with 59 alone for up to $50 \mathrm{~h}$ before heat-inactivation of the enzymes and addition of bacteria, the mutagenic activity did not decrease. It is concluded that the mutagenicity of emodin is due to a chemically stable, oxidized metabolite forming physico-chemical associations with DNA, possibly of the intercalative type. In order to check whether an intact mammalian organism might be able to activate emodin to a DNA-binding metabolite, radiolabelled emodin was administered by oral gavage to male SD rats and liver DNA was isolated after $72 \mathrm{~h}$. Very little radioactivity was associated with the DNA. Considering that DNA radioactivity could also be due to sources other than covalent interactions, an upper limit for the covalent binding index, $\mathrm{CBI}=(\mu$ moles chemical bound per moles DNA nucleotides)/(mmoles chemical administered per kg body weight) of 0.5 is deduced. This is $10^{4}$ times below the CBI of $\mathrm{AFB}_{1}$. The demonstration of a lack of covalent interaction with DNA both in Salmonella and in rat liver is discussed in terms of a reduced hazard posed by emodin as a mutagenic drug in use in humans.

Correspondence: Dr. U. Friederich, Institute of Toxicology, 
Emodin (1,6,8-trihydroxy-3-methylanthraquinone) is an important aglycone found in natural anthraquinone glycosides. 1,8-Dihydroxyanthraquinones of plants belonging to the families of Alloe, Cassia, Rhamnus and Rheum are frequently used as laxative drugs. About $70 \%$ of this kind of drug used in Switzerland contain anthraquinone derivatives (Codex Galenica, 1984). Furthermore, natural and synthetic anthraquinones are used as colouring agents in the food, cosmetics, and textile industries. Some anthraquinone derivatives are also used as cytostatics (Traganos, 1983) or show cytostatic activity in vivo (Driscoll et al., 1974). A high percentage of anthraquinone compounds exhibit mutagenicity in the Salmonella/mammalian microsome assay (Ames test). The majority including emodin is active with strain TA1537 (Brown and Brown, 1976; Brown and Dietrich, 1979; Tikkanen et al., 1983) which is reverted by intercalating agents such as 9aminoacridine (Ames et al., 1973). The strain specificity disappears by the substitution of anthraquinones with amino groups which leads to mutagenicity also with TA98 and TA1538 (Brown and Brown, 1976; Brown and Dietrich, 1979). The mutagenic activity of emodin is dependent on the addition of an activation system (Wehner et al., 1979; Brown, 1980; Libermann et al., 1982). No carcinogenic effects were found in a study conducted by Saffiotti and Shubik (1963) in mouse skin.

A great number of mutagens react covalently with DNA. If this type of genotoxic activity can be shown to be the mechanism of mutagenic action of emodin, a human exposure to anthraquinones would have to be considered in terms of a carcinogenic hazard despite the so far negative evidence in animal studies. The mechanism of mutagenic action of emodin in the Ames test and its ability to bind covalently to DNA of Salmonella and in rat liver was therefore investigated.

\section{Materials and methods}

Chemicals and apparatus. Emodin, ascorbic acid (vitamin C) and DMSO were obtained from Fluka AG, Buchs (Switzerland). Adriamycin was obtained from Farmitalia, Milano (Italy). Aflatoxin $B_{1}\left(A F B_{1}\right)$ was purchased from Senn $A G$,
Dielsdorf (Switzerland). Glutathione, NADP, glucose 6-phosphate, biotin, vitamin E (dl- $\alpha$ tocopherol) and SDS were obtained from Sigma, St. Louis, MO (U.S.A.). Hydrogen peroxide and silicagel plates were from Merck, Darmstadt, (F.R.G.), who also supplied all standard reagents of the highest purity available.

[G- $\left.{ }^{3} \mathrm{H}\right]$-Labelled aflatoxin $\mathrm{B}_{1}$, specific activity 8 $\mathrm{Ci} /$ mmole, was purchased from Moravek Biochemicals, Brea, CA (U.S.A.). It was diluted with unlabelled $A F B_{1}$ to a specific activity of 61 $\mathrm{mCi} / \mathrm{mmole}$.

Radioactivity measurements were carried out in Insta-Gel (Packard Instruments, Downers Grove, IL, U.S.A.) in a liquid scintillation counter, Packard Tri Carb 460 CD.

Synthesis of $\left[{ }^{14} \mathrm{C}\right]$ emodin. $\quad\left[10-{ }^{14} \mathrm{C}\right]$ Emodin (I) was synthesized from 3,5-dimethoxybenzoic $\left[{ }^{14} \mathrm{C}\right]$ acid methylester (II) and 2-methoxy-4-methyl benzoyl chloride (III) adapting the method of Hirose et al. (1973) to a millimolar scale: 3,5-dimethoxyaniline was converted by a Sandmeier reaction to 1-bromo-3,5-dimethoxybenzene which was labelled with $\left[{ }^{14} \mathrm{C}_{\mathrm{CO}}\right.$ (from $\mathrm{BaCO}_{3}, 50 \mathrm{mCi}$ )

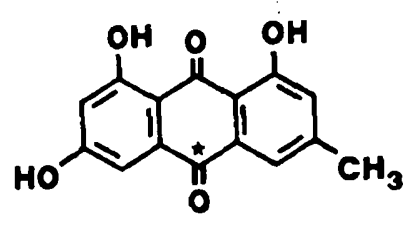

Chemical structure of emodin.

according to the procedure of Nguyen-HoangNam et al. (1974) followed by esterification with diazomethane to II. II was then reacted with III in a Friedel-Crafts acylation reaction and the resulting crude product subjected to ring condensation in a molten mixture of $\mathrm{AlCl}_{3} / \mathrm{NaCl}$. I was isolated from other anthraquinone compounds by column chromatography (benzene : ethyl acetate : acetic acid $90: 10: 1$ ) on silica and recrystallized from $\mathrm{CHCl}_{3}: \mathrm{MeOH}(95: 5)$ to yield chemically pure I as characterized by MS, IR and m.p.

The radiochemical purity was $>99 \%$ as checked by thin-layer chromatography on silica gel plates with toluene: ethyl acetate: acetic acid $(5: 4: 1)$ and benzene: methanol $(7: 2)$. The specific activity was $17.4 \mathrm{mCi} / \mathrm{mmole}$. 
Bacteria and activation system. Salmonella typhimurium strains TA1537, TA1977, TA1538, TA98, TA1535, TA100 and TA102 were kindly provided by B.N. Ames, University of California, Berkeley, CA (U.S.A.). Liver homogenate fractions $(9000 \mathrm{~g}$ supernatant prepared according to Ames et al., 1975) from Aroclor 1254-induced male Sprague-Dawley rats were used.

Standard Ames test and preincubation assay. Mutagenicity of emodin, adriamycin and hydrogen peroxide was determined using the plate-incorporation test as described by Ames et al. (1975). The influence of the $S 9$ concentration in the $S 9$ mix (usually $10 \%[\mathrm{v} / \mathrm{v}]$ ) on the mutagenicity of emodin in TA1537 was tested with the preincubation method $\left(30 \mathrm{~min}\right.$ at $\left.37^{\circ} \mathrm{C}\right)$ of Yahagi et al. (1977).

Mutagenicity and DNA binding. For the simultaneous determination of mutagenic effects and binding to bacterial DNA, the liquid preincubation method of Yahagi et al. (1977) was modified. Bacteria were grown overnight in 21 nutrient broth and the suspension was concentrated before use 10 -fold by centrifugation and resuspension in $200 \mathrm{ml}$ medium. Based on the composition used for one plate in the Ames agar plate assay $(0.5 \mathrm{ml}$ S9 $\mathrm{mix}, 0.1 \mathrm{ml}$ bacteria and $50 \mu 1$ solution of the substance in DMSO; final vol. $0.65 \mathrm{ml}$ ), a 500 -fold volume $(325 \mathrm{ml})$ was used. The mixtures containing $9.25 \mu$ moles $\left[{ }^{14} \mathrm{C}\right]$ emodin or $0.48 \mu$ moles $\left[{ }^{3} \mathrm{H}\right]$ aflatoxin $B_{1}$ were incubated in the dark for 90 $\mathrm{min}$ in a shaking water bath $(100$ cycles $/ \mathrm{min}$; $37^{\circ} \mathrm{C}$ ).

In the reaction mixtures without metabolic activation, a heat-inactivated $\mathrm{S} 9\left(30 \mathrm{~min}\right.$ at $\left.60^{\circ}\right)$ without cofactors was used in order to have an equal protein concentration. The loss of enzymatic activity was confirmed by the absence of mutagenicity after incubation with 2-aminoanthracene (2$\mathrm{AA}$, benzo[ $a$ ]pyrene (BaP) and 7,12-dimethylbenz $[a]$ anthracene (7,12-DMBA).

For the determination of viable cell counts, aliquots of the reaction mixtures were appropriately diluted with $0.85 \%(\mathrm{w} / \mathrm{v}) \mathrm{NaCl}$ to approximately 500 cells per $0.1 \mathrm{ml}$ and plated on minimal agar plates together with top agar supplemented with $0.3 \mathrm{mM}$ histidine. Two independent dilutions per incubation mixture were made.

In order to determine the mutagenic effects, an aliquot of the incubation mixtures $(5 \mathrm{ml}$ of 325 $\mathrm{ml}$ ) was centrifuged (2000 g for $20 \mathrm{~min}$ ) immediately after incubation. Bacteria were resuspended in $5 \mathrm{ml}$ cold $0.85 \% \mathrm{NaCl} / \mathrm{DMSO}(9: 1)$ and centrifuged again $(2000 \mathrm{~g}$ for $20 \mathrm{~min})$. The washed cells were resuspended in $5 \mathrm{ml}$ cold $0.85 \%$ $\mathrm{NaCl}$ before plating (3 replicate plates).

DNA was isolated from the bacterial pellet after centrifugation of the remaining incubation mixture at $8000 \mathrm{~g}$ for $10 \mathrm{~min}$ according to Viviani and Lutz (1978). $0.5-1 \mathrm{mg}$ purified DNA was obtained per $g$ wet bacterial pellet. The amount of DNA was determined by spectrophotometry on the basis of a UV absorbance of 20 at $260 \mathrm{~nm}$ for a solution of $1 \mathrm{mg} / \mathrm{ml}$. Radioactivity was determined by liquid-scintillation counting of an aliquot in $10 \mathrm{ml}$ Insta-Gel (Packard). DNA was reprecipitated with ethanol and the specific activity was determined again. These steps were repeated to constant specific activity to make sure that only covalently bound radiolabel remained on the bacterial DNA.

Influence of antioxidants. The effect of vita$\min \mathrm{C}$ and $\mathrm{E}$, and of glutathione (GSH) on TA1537 revertants induced by emodin was tested in the preincubation assay. The emodin concentration in the incubation mixture was $0.06 \mathrm{mM}$. Concentrations of vitamin $C$ and $E$ ranged from 0 to $6 \mathrm{mM}$, GSH concentration was $5 \mathrm{mM}$.

Chemical stability of the mutagenic principle of emodin. The Ames test was modified in the following manner: A reaction mixture containing 15 $\mathrm{ml} \mathrm{S9} \mathrm{mix}$ and $0.15 \mathrm{mg}$ of emodin (dissolved in 1.5 $\mathrm{ml}$ of DMSO) was held at $37^{\circ} \mathrm{C}$. For the first experiment, aliquots of $1.65 \mathrm{ml}$ were taken at various times up to $50 \mathrm{~h}$, mixed with $0.3 \mathrm{ml}$ overnight culture of TA1537 and plated together with $6 \mathrm{ml}$ top agar ( 3 replicate plates). For the second experiment, the incubation mixture ( $\mathrm{S} 9$ and emodin) was incubated for $1 \mathrm{~h}$ at $37^{\circ} \mathrm{C}$ followed by $30 \mathrm{~min}$ at $60^{\circ} \mathrm{C}$ to inactivate the drug metabolism enzymes. The reaction mixture was then cooled to $37^{\circ} \mathrm{C}$ and kept at this temperature for up to $50 \mathrm{~h}$. During this time aliquots of 1.65 
$\mathrm{ml}$ were mixed with bacteria and top agar and were plated.

DNA binding in rat liver. Two $250 \mathrm{~g}$ female Sprague-Dawley rats received by oral gavage in polyethylene glycol (PEG 400) 3.57 and $3.32 \mathrm{mCi}$ $\left[{ }^{14} \mathrm{C}\right]$ emodin per $\mathrm{kg}$ body weight $(53 \mathrm{mg} / \mathrm{kg})$. The animals were killed with ether after $72 \mathrm{~h}$ and DNA was isolated from the liver via chromatin according to Sagelsdorff et al. (1983). DNA isolated from an untreated rat served as radioactivity background for the determination of the specific activity.

\section{Results}

Mutagenicity. Table 1 shows that emodin produced a clear mutagenic effect only with strain 1537 and only in the presence of a mammalian activation system. A borderline effect was also observed with TA100 and rat-liver activation. A linear dose-response relationship was seen up to $10 \mu \mathrm{g}$ emodin per plate. In TA1537 the mutagenic activity with $10 \mu \mathrm{g}$ emodin per plate increased linearly with the concentration of S9 up to $10 \%$ in the S9 mix (Fig. 1). Between 10 and 20\% the number of revertants increased very slowly and between 20 and $30 \%$ no further increase could be observed. The mutagenic activity of emodin could be achieved only in the presence of active S9; after the addition of heat-inactivated $\mathrm{S} 9(30 \mathrm{~min}$, $60^{\circ} \mathrm{C}$ ) no mutagenicity was detected (Table 2). Addition of the cytochrome-P448 inhibitor 7,8-

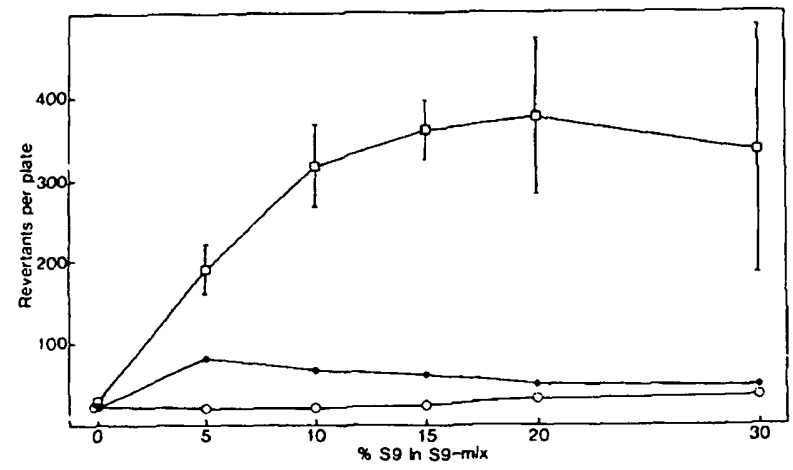

Fig. 1. Mutagenicity of emodin ( $2 \mu \mathrm{g}$ per plate [ $\star$ ]; $10 \mu \mathrm{g}$ per plate [ㅁ]; control [O]) after addition of $S 9 \mathrm{mix}$ with different concentrations of $S 9(\%[v / v])$.
TABLE 1

MUTAGENICITY OF EMODIN FOR DIFFERENT $S$ typhimurium STRAINS

Mean and standard deviation of triplicates.

\begin{tabular}{|c|c|c|c|c|}
\hline \multirow{2}{*}{$\begin{array}{l}\text { Dose } \\
(\mu \mathrm{g})\end{array}$} & \multirow{2}{*}{$\begin{array}{l}\text { Activa- } \\
\text { tion } \\
\text { Rat-liver S9 }\end{array}$} & \multicolumn{3}{|c|}{ Revertants per plate } \\
\hline & & TA1537 TA1538 & TA98 TA1535 & TA100 \\
\hline 0 & + & $\begin{array}{ll}7 \pm 1 & 20 \pm 3 \\
8 \pm 1 & 30 \pm 3\end{array}$ & $\begin{array}{ll}15 \pm 6 & 66 \pm 5 \\
26 \pm 6 & 23 \pm 1\end{array}$ & $\begin{array}{l}192 \pm 4 \\
200 \pm 6\end{array}$ \\
\hline 2 & $\begin{array}{l}- \\
+\end{array}$ & $\begin{array}{r}9 \pm 2 \\
84 \pm 11\end{array}$ & & \\
\hline 10 & $\begin{array}{l}- \\
+\end{array}$ & $\begin{array}{r}11 \pm 4 \\
427 \pm 34\end{array}$ & & \\
\hline 20 & - & $\begin{array}{l}21 \pm 4 \\
31 \pm 7\end{array}$ & $\begin{array}{ll}19 \pm 4 & 71 \pm 8 \\
28 \pm 1 & 26 \pm 3\end{array}$ & $\begin{array}{l}201 \pm 5 \\
312 \pm 24\end{array}$ \\
\hline 40 & $\begin{array}{l}- \\
+\end{array}$ & $\begin{array}{r}15 \pm 4 \\
438 \pm 22\end{array}$ & $\begin{array}{l}23 \pm 6 \\
31 \pm 1\end{array}$ & \\
\hline 80 & $\overline{+}$ & 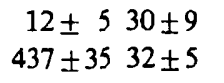 & $\begin{array}{ll}14 \pm 2 & 62 \pm 8 \\
24 \pm 6 & 24 \pm 9\end{array}$ & $\begin{array}{l}209 \pm 15 \\
319 \pm 29\end{array}$ \\
\hline
\end{tabular}

benzoflavone inhibited the mutagenic activity of emodin towards TA1537 (Fig. 2, left-hand side). The mutagenicity of $\mathrm{BaP}$ was also reduced by the addition of this inhibitor. Metyrapone, on the

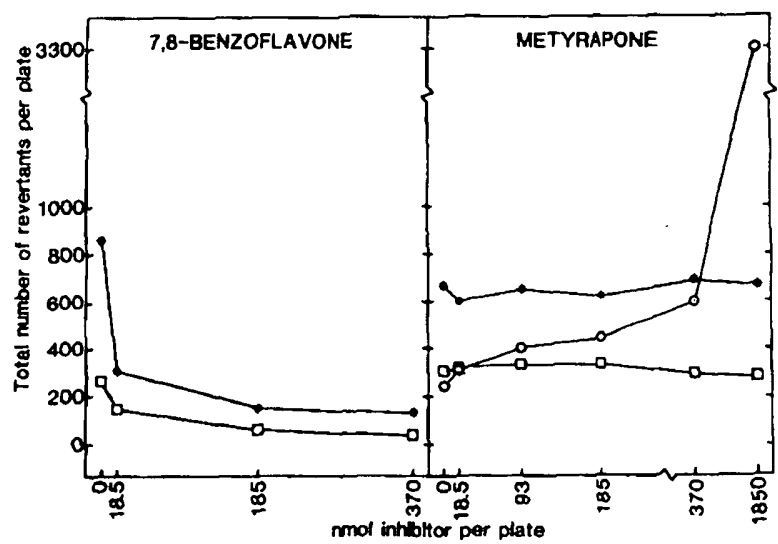

Fig. 2. Influence of cytochrome P-448/P-450 inhibitors on the mutagenic activity of emodin ( $5 \mu \mathrm{g}$ per plate [0]) and two standard promutagens (5 $\mu \mathrm{g}$ BaP per plate [ $\star \star ; 1 \mu \mathrm{g} 2$-AA per plate [O]). The test compounds were preincubated in a total volume of $1.8 \mathrm{ml}$ containing $1.5 \mathrm{ml} \mathrm{10 \%} \mathrm{(v/v)} \mathrm{S9} \mathrm{mix} \mathrm{and}$ different amounts of the respective inhibitor for $30 \mathrm{~min}$ at $37^{\circ} \mathrm{C}$ before the addition of $0.3 \mathrm{ml}$ bacteria (TA1537 for emodin; TA98 for BaP and 2-AA) and $6.0 \mathrm{ml}$ top agar. The suspension was thoroughly mixed and plated on 3 replicate plates. 
TABLE 2

MUTAGENIC ACTIVITY OF EMODIN AND OF STANDARD PROMUTAGENS AFTER ADDITION OF ACTIVE OR HEAT-INACTIVATED S9

\begin{tabular}{llrrr}
\hline Mutagen $(\mu \mathrm{g} /$ plate $)$ & $\begin{array}{l}\text { Salmo- } \\
\text { nella } \\
\text { strain }\end{array}$ & \multicolumn{3}{l}{$\begin{array}{l}\text { Total number of revertants } \\
\text { per plate }\end{array}$} \\
\cline { 3 - 5 } & & $\mathrm{S}^{-\mathrm{a}}$ & $\mathrm{S}^{+}$ & $\begin{array}{l}\mathrm{S9}^{+} \\
\text {inactiv. }\end{array}$ \\
\hline Emodin $(10 \mu \mathrm{g})$ & TA1537 & $8 \pm 1$ & $324 \pm 23$ & $9 \pm 1$ \\
2-AA $(1 \mu \mathrm{g})$ & TA1537 & $8 \pm 1$ & $33 \pm 3$ & $7 \pm 4$ \\
BaP $(5 \mu \mathrm{g})$ & TA98 & $22 \pm 4$ & $628 \pm 33$ & $26 \pm 5$ \\
$7,12-D M B A(10 \mu \mathrm{g})$ & TA98 & $24 \pm 2$ & $265 \pm 15$ & $32 \pm 5$ \\
\hline
\end{tabular}

addition of buffer instead of S9.

other hand, an inhibitor of the cytochrome P-450dependent monooxygenases, did not reduce the mutagenicity of emodin or $\mathrm{BaP}$. The mutagenic effect of 2-AA was even increased (Fig. 2, righthand side). It is concluded that the mutagenicity of emodin is dependent on a metabolic, oxidative process controlled by cytochrome P-448-dependent monooxygenases.
Mutagenicity and DNA binding. In order to investigate whether the observed mutagenicity in TA1537 was due to covalent DNA binding, $\left[{ }^{14} \mathrm{C}\right]$ emodin was used in a large-scale incubation so that enough DNA could be isolated from the bacteria to detect bound emodin. The concentration of $\left[{ }^{3} \mathrm{H}\right]$ aflatoxin $B_{1}$ used in parallel incubations as positive control was about 20 times lower to give approximately the same mutagenic response as emodin. The data are presented in Table 3. Mutagenicity of emodin and bacterial. survival were lower than in the standard tests, probably due to the additional washings. This was done to remove the test compounds from the preincubation mixture so that no additional mutagenicity could be exerted on the plates.

DNA obtained from the aflatoxin-treated Salmonella could be purified to a constant specific activity (after the 2nd precipitation) indicating that the mutagen was bound covalently. With emodin, the specific activity of DNA did not remain constant after repeated precipitations. Already after the 2 nd precipitation no difference was seen between the incubation mixtures with active and heat-inactivated S9. This behaviour is not

TABLE 3

MUTAGENICITY AND DNA BINDING OF $\left[{ }^{14} \mathrm{C}\right]$ EMODIN AND $\left[{ }^{3} \mathrm{H}\right] A F B_{1}$ IN TA1537

\begin{tabular}{|c|c|c|c|c|}
\hline & $\mathrm{E}^{-}$ & $\mathrm{E}^{+}$ & $\mathrm{A}^{-}$ & $\mathrm{A}^{+}$ \\
\hline \multicolumn{5}{|l|}{ Incubation } \\
\hline Mutagen in $325 \mathrm{ml}$ incub. mix. ( $\mu$ moles) & 9.25 & 9.25 & 0.48 & 0.48 \\
\hline Spec. act. $\left(10^{7} \mathrm{dpm} / \mu\right.$ mole $)$ & 3.86 & 3.86 & 13.6 & 13.6 \\
\hline \multicolumn{5}{|l|}{ Mutagenicity } \\
\hline Induced revertants per plate ${ }^{a}$ & 0 & 11 & 0 & 64 \\
\hline \multicolumn{5}{|l|}{ DNA binding } \\
\hline DNA (mg) isolated & 4.2 & 4.2 & 5.0 & 4.2 \\
\hline \multicolumn{5}{|l|}{ Specific activity (dpm per mg DNA) } \\
\hline 1st precipitation & 11 & 17 & $<60$ & 1150 \\
\hline 2nd precipitation & 11 & 11 & $<60$ & 1120 \\
\hline 3rd precipitation & 7 & 6 & \multicolumn{2}{|c|}{ constant } \\
\hline Bound mutagen (pmoles per mg DNA ${ }^{b}$ ) & $\leqslant 0.28$ & $\leqslant 0.28$ & $<0.44$ & 8.5 \\
\hline Bound molecules per Salmonella genome ${ }^{b, c}$ & $\leqslant 0.8$ & $\leqslant 0.8$ & $<1.2$ & 24 \\
\hline
\end{tabular}

$E^{-}, A^{-}:$Emodin resp. $A_{F B}$ incubated with heat-inactivated $S 9$.

$\mathrm{E}^{+}, \mathrm{A}^{+}$: Emodin resp. $\mathrm{AFB}_{1}$ incubated with active $\mathrm{S} 9$.

${ }^{a}$ Induced revertants in $0.65 \mathrm{ml}$ incubation mix (the value for the sample with inactivated S9 was subtracted; mean values of 6 replicate plates).

b Related to the 2nd DNA precipitation.

c Calculated on the assumption that the average molecular weight of one nucleotide is 309 and that the mean nucleotide content is $9 \times 10^{6}$ per Salmonella genome (Drake, 1969). 
compatible with a covalent binding so that the mutagenicity of the emodin metabolite is unlikely to involve covalent interaction with Salmonella DNA.

Influence of antioxidants. The mutagenicity must therefore be due either to non-covalent interaction of an oxidized metabolite with DNA or to the production of oxygen-derived radicals which might be formed during emodin metabolism. The latter possibility was rendered unlikely, however, by the use of strain TA102 which should specifically be reverted by oxygen radical-generating compounds such as peroxides. Emodin was negative in this strain, and the two strains TA102 and TA1537 showed a completely different response pattern with $\mathrm{H}_{2} \mathrm{O}_{2}$, adriamycin and emodin (Fig. 3). Furthermore, the use of the antioxidants vita$\min C$ and $E$ and of glutathione did not lead to a decrease in the number of TA1537 revertants induced by emodin (Table 4).
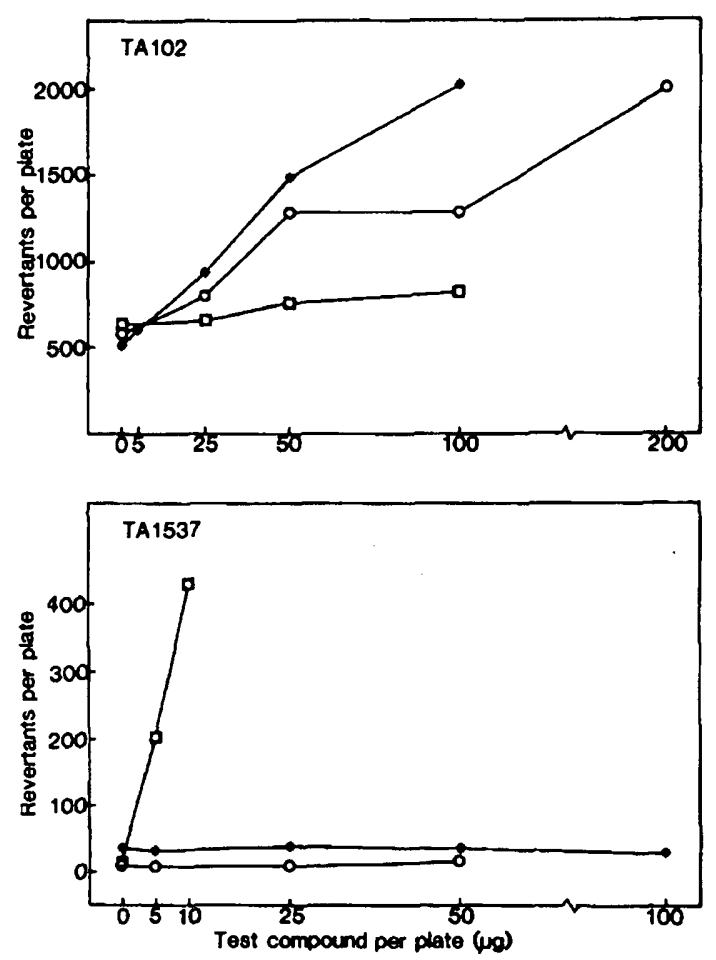

Fig. 3. Mutagenicity in the plate-incorporation procedure in Salmonella strains TA102 and TA1537 of emodin (口, $\mathrm{S9}^{-}=\mathrm{S}^{+}$ with $\mathrm{TA102}, \mathrm{S}^{+}$with $\left.\mathrm{TA1537}\right)$, adriamycin $\left(*, \mathrm{~S} 9^{-}=\mathrm{S} 9^{+}\right)$, and hydrogen peroxide $\left(\mathrm{O}, \mathrm{S}^{-}\right.$with $\mathrm{TA102}, \mathrm{S} 9^{-}=\mathrm{S} 9^{+}$with TA1537). Results of 2 independent experiments.
TABLE 4

THE INFLUENCE OF DIFFERENT ANTIOXIDANTS OR RADICAL SCAVENGERS ON THE MUTAGENIC ACTIV. ITY OF EMODIN FOR TA1537

\begin{tabular}{lrrr}
\hline $\begin{array}{l}\text { Compound } \\
\text { ( } \mu \mathrm{g} \text { per plate) }\end{array}$ & \multicolumn{2}{l}{ Total number of revertants per plate \pm SD } \\
\cline { 2 - 3 } & \multicolumn{2}{l}{ Emodin ( $\mu \mathrm{g}$ per plate) } \\
\cline { 2 - 4 } & 0 & 5 & 10 \\
\hline $\begin{array}{c}\text { Vitamin } C \\
0\end{array}$ & $10 \pm 3$ & - & $351 \pm 36$ \\
65 & $7 \pm 5$ & - & $329 \pm 22$ \\
650 & $7 \pm 1$ & - & $385 \pm 59$ \\
Vitamin E & & & \\
0 & $7 \pm 0$ & - & $344 \pm 38$ \\
160 & $8 \pm 1$ & - & $348 \pm 30$ \\
1600 & $10 \pm 1$ & - & $366 \pm 60$ \\
GSH & & & \\
0 & $20 \pm 3$ & $173 \pm 10$ & $232 \pm 23$ \\
7.7 & $18 \pm 3$ & $197 \pm 8$ & $264 \pm 21$ \\
\hline
\end{tabular}

Bacteria, emodin, S9 mix and the different compounds were preincubated for $20 \mathrm{~min}$ at $37^{\circ} \mathrm{C}$ before plating. For the experiment with GSH a separate top agar layer containing S9, emodin and GSH was plated on the dried top agar containing bacteria.

Chemical stability of the mutagenic principle of emodin. The mutagenicity of emodin to TA1537 was not reduced when the bacteria were added to the incubation mixture only after preincubation of emodin with $\mathrm{S} 9$ and heat inactivation of the enzymes (Fig. 4; $\star$ ). The same value of stable mutagenicity was also obtained when the preincubation of emodin and S9 lasted between 6 and $50 \mathrm{~h}$ before the addition of TA1537 and plating (no heat inactivation; Fig. 4; O). The higher mutagenicity obtained after preincubation of emodin and S9 for up to $6 \mathrm{~h}$ can be interpreted as a result of additional activation on the plates. The continuous decrease of the mutagenic activity between 1 and $6 \mathrm{~h}$ is most probably due to the slow inactivation of the monooxygenases at $37^{\circ} \mathrm{C}$. The most important point of the results presented in Fig. 4 is, however, the fact that the mutagenic principle produced by emodin in the presence of rat-liver enzymes must be stable. This stability would not have been expected with oxygen radicals.

DNA binding in rat liver. The specific activity of the DNA samples was 12 and $21 \mathrm{dpm} / \mathrm{mg}$. 


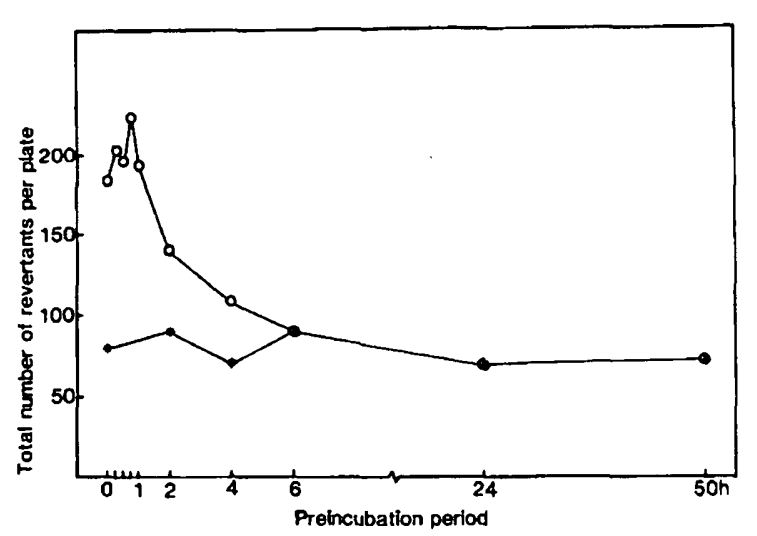

Fig. 4. Stability of the mutagenic emodin metabolites. Preincubation of emodin and $\mathrm{S} 9 \mathrm{mix}$ at $37^{\circ} \mathrm{C}$ and determination of the mutagenic activity after different incubation periods before the addition of bacteria $(O)$. Heat inactivation $\left(30 \mathrm{~min}, 60^{\circ} \mathrm{C}\right.$ ) of the suspension containing $\mathrm{S} 9 \mathrm{mix}$ and emodin after $1 \mathrm{~h}$ at $37^{\circ} \mathrm{C}$ and determination of the mutagenic activity thereafter $(\star)$.

This was too low for a nucleotide analysis which would have allowed the subtraction of that part of the radioactivity which might have been incorporated into DNA from radiolabelled breakdown products by de novo DNA synthesis. Expressed in the units of the Covalent Binding Index (Lutz, 1979), $\mathrm{CBI}=(\mu$ moles chemical bound per mole DNA-nucleotides)/(mmoles chemical administrated per $\mathrm{kg}$ body weight) upper limit values of 0.5 and 0.9 resulted. This is about 10000 times below the CBI for aflatoxin $B_{1}$ (Lutz, 1979) and in a range which makes it highly unlikely that covalent binding will lead to increased tumour formation in a standard bioassay on carcinogenicity.

\section{Discussion}

The results of the present work suggest that the observed mutagenicity of emodin is a result of a stable oxidation product formed under the control of cytochrome P448-dependent monooxygenases. Because of the much stronger response of strain TA1537 in comparison to TA100 and because of the lack of covalent reactivity with DNA, the responsible emodin metabolite(s) most probably induce exclusively frameshift-type mutations as a consequence of a physico-chemical association, perhaps by intercalation, with Salmonella DNA. The data are in agreement with a recent report of
Masuda and Ueno (1984) showing that a 2hydroxylation can activate an anthraquinone ring system to a mutagen for TA1537 requiring no further activation.

The data on rat-liver DNA binding also suggest that an intact mammalian liver is unlikely to be able to activate emodin to metabolites which could react covalently with DNA to any appreciable extent.

An assessment of the carcinogenic risk to humans from exposure to emodin and to structurally related anthraquinone mutagens must therefore take the following into account: (i) The mutagenicity of emodin in strain TA1537 which was also reported for other anthraquinones (Brown and Dietrich, 1976) is not due to covalent binding of the compound to Salmonella DNA. (ii) We are not aware of any report showing that a mutagen which exclusively reverts strain TA1537 has carcinogenic activity in animals. (iii) No relationship exists between intercalative mutagenicity in short-term assays and carcinogenicity.

Dibenz $[a, h]$ anthracene-5,6-oxide, a mutagen which was reported to be also positive only in $S$. typhimurium TA1537, is not an animal carcinogen (Grover et al., 1975). Chloroquin and quinacrin showing the same spectrum of mutagenic activity most probably have no carcinogenic activity (Fitzhugh et al., 1945, 1948). (iiii) There is no conclusive evidence for a carcinogenic activity in animals for anthraquinone derivatives such as hydroxyanthraquinones, whereas carcinogenicity has been reported for an anthraquinone bearing a nitro group, 2-methyl-1-nitroanthraquinone (Murthy et al., 1979). In addition, nitroanthraquinones are mutagenic in Salmonella strains TA98, TA1538 and TA100 thus showing a different pattern of mutagenic activity as compared with emodin (Brown and Brown, 1976; Brown and Dietrich, 1979).

Despite the positive results in the Ames test, our analysis suggests that emodin is unlikely to represent a high priority risk in human mutagen exposure.

\section{Acknowledgement}

This work was supported by the Swiss National Science Foundation (Grant No. 3.844-0.81). 


\section{References}

Ames, B.N., F.D. Lee and W. Durston (1973) An improved bacterial test system for the detection and classification of mutagens and carcinogens, Proc. Natl. Acad. Sci. (U.S.A.), 70, 782-786.

Ames, B.N., J. McCann and E. Yamasaki (1975) Methods for detecting carcinogens and mutagens with the Salmonella/ mammalian-microsome mutagenicity test, Mutation Res., 31, 347-364.

Brown, J.P. (1980) A review of the genetic effects of naturally occurring flavonoids, anthraquinones and related compounds, Mutation Res., 75, 243-277.

Brown, J.P., and R.J. Brown (1976) Mutagenesis by 9,10anthraquinone derivatives and related compounds in Salmonella typhimurium, Mutation Res., 40, 203-224.

Brown, J.P., and P.S. Dietrich (1979) Mutagenicity of anthraquinone and benzanthrone derivatives in the Salmonella/ microsome test: activation of anthraquinone glycosides by enzymic extracts of rat cecal bacteria, Mutation Res., 66, 9-24.

Codex Galenica (1984) Dokumentation Galenica Bern.

Drake, J.W. (1969) Comparative rates of spontaneous mutation, Nature (London), 221, 1128-1132.

Driscoll, J.S., G.F. Hazard Jr., H.B. Wood Jr. and A. Goldin (1974) Structure-antitumor activity relationships among quinone derivatives, Cancer Chemotherap. Rep., 4, 1-362.

Fitzhugh, O.G., A.A. Nelson and H.O. Calvery (1945) The chronic toxicity of quinacrine (atabrine), J. Pharmacol. Exp. Ther., 85, 207-221.

Fitzhugh, O.G., A.A. Nelson and O.L. Holland (1948) The chronic oral toxicity of chloroquin, J. Pharmacol. Exp. Ther., 93, 147-152.

Grover, P.L., P. Sims, B.C. Mitchley and F.J. Roe (1975) The carcinogenicity of polycyclic hydrocarbons in newborn mice, Br. J. Cancer, 31, 182-188.

Hirose, Y., M. Kuroiwa, H. Yamashita, T. Tanaka and T. Megumi (1973) Chemical studies on the natural anthraquinones, Chem. Pharm. Bull., 21, 2790-2793.

Libermann, D.F., R.C. Fink, F.L. Schaefer, R.J. Mulcahy and
A.-A. Stark (1982) Mutagenicity of anthraquinone and hydroxylated antraquinones in the Ames Salmonelia/microsome system, Appl. Environ. Microbiol., 43, 1354-1359.

Lutz, W.K. (1979) In vivo covalent binding of organic chemicals to DNA as quantitative indicator in the process of chemical carcinogenesis, Mutation Res., 65, 289-356.

Masuda, T., and Y. Ueno (1984) Microsomal transformation of emodin into a direct mutagen, Mutation Res., 125, 135-144.

Murthy, A.S., A.B. Russfield, M. Hagopian, R. Monson, J. Snell and E.K. Weisburger (1979) Carcinogenicity and nephrotoxicity of 2-amino-, 1-amino-2-methyl-, and 2methyl-1-nitro-anthraquinone, Toxicol. Lett., 4, 71-78.

Nguyen-Hoang-Nam, J.P. Baucourt, H. Hoellinger and L. Pichet (1974) Synthèse du (dihydroxy-3,5-phenyl)-1 pentane $\left[{ }^{14} \mathrm{C}-1\right]$ ou olivetole $\left.{ }^{14} \mathrm{C}-7\right]$ (châne latérale), Bull. Soc. Chim. (France), 7-8, 1367-1368.

Saffiotti, U., and P. Shubik (1963) Studies on promoting action in skin carcinogenesis, Natl. Cancer Inst., Monogr., 10. 489-507.

Sagelsdorff, P., W.K. Lutz and Ch. Schlatter (1983) The relevance of covalent binding to mouse liver DNA to the carcinogenic action of hexachlorocyclohexane isomers, Carcinogenesis, 4, 1267-1273.

Tikkanen, L., T. Matsushima and S. Natori (1983) Mutagenicity of anthraquinones in the Salmonella preincubation test, Mutation Res., 116, 297-304.

Traganos, F. (1983) Dihydroxyanthraquinone and related bis(substituted)aminoanthraquinones a novel class of antitumor agents, Pharmacol. Ther., 22, 199-214.

Viviani, A., and W.K. Lutz (1978) Modulation of the binding of the carcinogen benzo[ $a]$ pyrene to rat liver DNA in vivo by selective induction of microsomal and nuclear aryl hydrocarbon hydroxylase activity, Cancer Res., 38, 4640-4644.

Wehner, C.F., P.G. Thiel and M. DuRand (1979) Mutagenicity of the mycotoxin emodin in the Salmonella/microsome system, Appl. Environ. Microbiol., 37, 658-660.

Yahagi, T., M. Nagao, Y. Seino, T. Matsushima, T. Sugimura and M. Okada (1977) Mutagenicities of $N$-nitrosamines on Salmonella, Mutation Res., 48, 121-130. 